CATHARSIS 9 (3) 2020

Halaman: 232-243

p-ISSN 2252-6900 I e-ISSN 2502-4531

UNNES

Catharsis: Journal of Arts Education

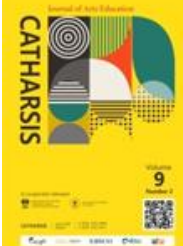

http://journal.unnes.ac.id/sju/index.php/chatarsis

\title{
The Preservation of the Terbang Papat Music at Ash-Shiddiqin Musalla in Kudus Regency
}

\author{
Mylza Novaryandana ${ }^{1 \bowtie}$, Totok Sumaryanto Florentinus ${ }^{2}$, Udi Utomo ${ }^{2}$ \\ E-mail: sabrinasarah1994@gmail.com \\ 1. SMA Negeri 1 Pecangaan, Indonesia \\ 2. Universitas Negeri Semarang, Indonesia
}

Received 27 April 2020, Accepted 28 August 2020, Published 23 December 2020

\begin{abstract}
Terbang Papat is a typical traditional art from Kudus, the name of Terbang Papat was taken from the instruments of Terbang in the amount of four and used one Jidor. The art of Terbang Papat, now is starting to fade because it has been replaced by the times. This study aims to provide a preservation overview of the Terbang Papat art form in Kudus. The study was conducted by using a qualitative analysis research method with the research location in the Kedungdowo Kaliwungu village, Kudus Regency. The data collection techniques used observation, interviews, and document study. The data validity technique used data triangulation technique. Meanwhile, data analysis and processing techniques were carried out by collecting, reducing, clarifying and verifying data. The result of preserving the Terbang Papat music is from musical elements namely the time element and the characteristics of the accompanying instruments.
\end{abstract}

Keywords: Preservation, Musical Forms, Terbang Papat

DOI : https://doi.org/ 10.15294/ catharsis.v9i3.45272 


\section{INTRODUCTION}

Rebana is the result of acculturation of Javanese culture and Arabic culture, Rebana is a traditional musical art created since the Walisongo era, which was previously used as a da'wah medium, Rebana was estimated developed in the Javanese Pantura around the XVI century until now (Sinaga, 2002: 4). In the Pantura/ Coastal areas of Central Java, namely Kudus, Pati, Jepara, Demak, and Rembang, the art of rebana is often called Terbang. The art of Terbang or Rebana based on the times and innovations in Java is very diverse, has many types, and appearances. The type of Terbang music or Rebana music, including; Terbang Balo-balo from Tegal, Terbang Kentrung from Jepara and Rembang, Terbang Zapin from Demak, Terbang Genjring from Pemalang, and Terbang Papat from Kudus (Junaidi, 2015: 33)

Terbang Papat is a typical traditional art from Kudus, the name of Terbang Papat was taken from the Terbang instruments which has four instruments and used one Jidor. The art of Terbang Papat is starting to fade because it has been replaced by the times. This is in line with Relianto's (2015) statement who states that the art of Terbang Papat in Kudus is almost extinct, due to the lack of public appreciation for regional arts, Based on this reason there were several groups observing traditional arts in Kudus, so a Forum namely Forum Komunikasi Terbang Papat ((FKTP (Communication Forum of Terbang Papat)) was formed.

Related to the preservation of regional arts, it is in line with the writings of Sukari (2012) which describes efforts to preserve the existence of regional arts, especially music and songs that need support and cooperation from all elements, namely government, art actors, community and the private sector. Preservation is an effort to generate something on to future generations or young people who are ready to preserve. Preservation in the younger generation has three ways, namely school, family and community. In addition, the efforts to preserve regional arts, provide economic value for the welfare of traditional art actors, empower traditional musical art groups to the younger generation from an early age were also conducted. Based on Sukari's writing, it became a reason for researchers on the preservation of the Terbang Papat at Ash-Shiddiqin Musalla in Kudus, which is related to the support of the government, art actors, the community, and in collaboration with school and family.

Prier (1996: 2) the form of music can also be seen practi cally as a 'medium' which is 'filled' by a composer and processed in such a way that it becomes living music. The notion of the structure of a work of art is an aspect that relates to the composer's overall work (Fitria 2010: 72) and it is processed in such a way that it becomes living music. Therefore, the elements of time are the foundation for music. In music, this element is divided into three factors, namely: tempo, meter, and rhythm.

Tempo is a term from Italian which literally means: time, and in music indicates the speed. The level of speed is a metronome which was previously very common to show tempo with only a few general terms, namely: presto (very fast), allegro (fast), vivace (live), moderato (moderate), andante (rather slow), adagio (slower than Andante), lento (slow), largo (very slow), and others. Meanwhile, Benward \& Saker (2008: 393) states that tempo is the speed of rhythm in music, which can be expressed in general or in beats per minute.

Meters in writing are indicated by a sukat sign indicating the number of beats for a bar. The bars are indicated by drawing vertical lines on the staff line. The most common meters are two beats for a bar (sukat two); three beats for one bar (sukat three); four beats per time (sukat four or meter in general); and two or more groups of three for one bar (structure of sukatsukat; 6/8, 9/8, and 12/8) (Miller 2017: 67).

Rhythm can be assumed as an element of time in music that is produced by two factors, namely: 1) accent, and 2) short-note length or duration. An accent is the stress or emphasis on a note to make it sound louder. Various combinations of notes of different durations 
produce rhythm, namely the choice of long and short notes, two short notes and a long note, or a long note with several short notes (Miller 2017: 67). In all these elements, according to Miller, it becomes the basis for a music, and it is used by researchers to analyze the form of music in the art of Terbang Papat at AshShiddiqin Musalla in Kedungdowo Village, Kaliwungu District, Kudus.

In the art of Terbang Papat at AshShiddiqin Musalla in Kedungdowo Village, Kaliwungu District, Kudus by using musical instruments in the amount of 4 Terbang instruments and 1 Jidor were song so that it could visualize tones that could be heard by ears, it required musical notation in musicology. According to Martinus (2001: $404)$, notation is a process of making tone signs. Meanwhile, according to Banoe (2003: 299) notation is a symbol or musical writing. So it can be interpreted that notation is a way of writing a sign or tone symbol. Types of musical notation that are commonly known are number notation and block notation. In the art of Terbang Papat, the notation used by researchers to visualize the rhythm of the Terbang musical instruments and Jidor and the notes that are sung is block notation.

\section{METHOD}

The method used in this study is qualitative research methods. Qualitative research is descriptive research, it does not use numbers, and describes the form of words, writings and observations (Kaelan (2012: 5). The approach used in this study is an interdisciplinary approach, which is to use more than one discipline into one Rohidi, 2011: 65). In this study, the disciplines used are musicology and sociology. Musicology to analyze the form of the Terbang Papat music at Ash-Shiddiqin Musalla in an effort to preserve the art of Terbang Papat at Ash-Shiddiqin Musalla, Kedungdowo Village, Kaliwungu District, Kudus.

The location of the study is related to the study carried out by the researcher in the Ash-
Shiddiqin Musalla, Kedungdowo Village, Kaliwungu District, Kudus.

The data collection techniques used in this study, namely, observation, interviews, and document study. The observations made by researchers were conducted by visiting the research location. In this study, the interview technique was carried out in a structured manner with interviewees or informants.

The document study technique could also be equipped by tracing the art of Terbang Papat at Ash-Shiddiqin Musalla from internet sites and communities around Kedungdowo village or artists who had researched or been involved in the Terbang Papat art activity at AshAshiddiq Musalla.

The data validity checking technique used in this study was based on credibility criteria, using triangulation techniques. Analysis of the data used in this study refers to the analysis of Miles and Huberman translated by Rohidi (2011, p. 238). The analysis process was carried out with a cycle model starting from data collection, reducing data and clarifying, concluding and interpreting all information selectively.

\section{RESULTS AND DISCUSSION}

In Kaliwungu Subdistrict, there was a Musholla which was quite famous for Terbang Papat performers and Terbang Papat lovers in Kaliwungu District and its surroundings, the prayer room called Ash-Shiddiqin, the Musalla was famous for having a Terbang Papat group whose existence was still maintained until now. Ash-Shiddiqin Musalla was located in Kedungdowo Village, RT $02 \quad\left(2^{\mathrm{ND}}\right.$ neighbourhood) RW 04 ( $4^{\text {th }}$ hamlet) Kaliwungu District

\section{Berjanzenan}

Berjanzenan (praying by using the verses in the book of Alberjanzi) regularly accompanied by the game of Terbang Papat which was conducted once a week in every Wednesday night after the evening prayer 'and this activity continued until now. Berjanzenan 
was conducted by using a loudspeaker/ microphone of the Ash-Shiddiqin Musalla, this was conducted to attract the interest of the people of Kedungdowo Hamlet and its surroundings to join Berjanzenan and played Terbang Papat so that the members of the Terbang Papat at Ash-Shiddiqin Musalla group would increase. This method was also a sign/ code for members of the Terbang Papat group, to immediately gather. Even though the members were increasing, when Berjanzenan the number of members who could gather was not fixed, it could be a little or a lot, because each member also had other activities, and Berjanzenan activities were activities that were not mandatory, because Berjanzenan activities were activities carried out based on pleasure/ hobbies and concern for the existence of Terbang Papat so that it remains sustainable. The following was a documentation when Berjanzenan at the Ash-Shiddiqin Mosque.

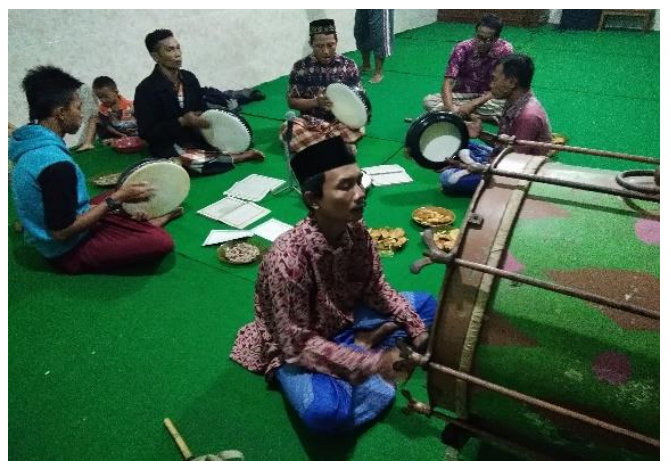

Figure 1. Berjanzenan in Ash-Ashiddiqin Musalla

(Doc. Mylza, 2019)

From the Berjanzenan activities at the Ash-Shiddiqin Mosque, Terbang Papat Group at Ash-Shiddiqin Musalla became known to the wider community, and was often invited by Berjanzenan in community events around Kaliwungu Kudus District. At the beginning of the establishment of the Terbang Papat at AshShiddiqin Musalla, it was usually invited to attend the event (entertainment event on the night before the party), it was used to shift gambling activities when it was running. The following is a documentation when invited to a ceremony to carry out circumcision at one of Mr. Warsono's houses, a resident of Kedungdowo Hamlet, Kedungdowo Village.

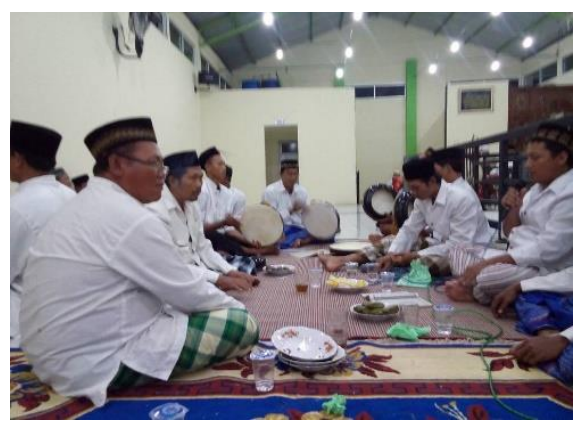

Figure 2. Melekan Khitan at Mr. Warsono's house

(Doc. Mylza 2019)

\section{Familiarity Activities}

In addition to Berjanzenan activities, the Tembang Papat Group at Ash-Shiddiqin Musalla also had a routine agenda to maintain familiarity and kinship among members, namely through the guardian pilgrimage and Halal Bihalal which was held every year. Funds for these activities were obtained from generous donations from Berjanzenan activities that were carried out when invited to community events. The following is a documentation of the pilgrimage activities of guardians and Halal Bihalal.

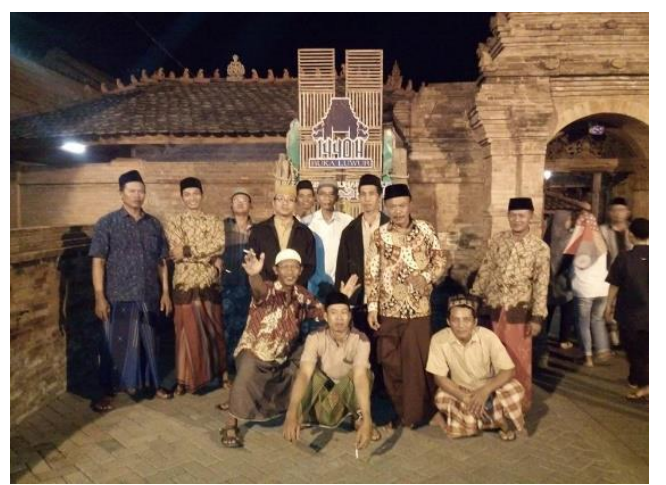

Figure 3. Terbang Papat Group Ash- Shiddiqin Musalla when pilgrimage at the Tomb of Sunan Kudus

(Source: Mr. Muhib Yasin) 


\section{Performers of the Terbang Papat at Ash- Shiddiqin Musalla}

The performers of the Terbang Papat art at the Ash-Ashiddiqin Musalla were dominated by the elderly, with about 30 members, and on average of them were 40 years and over. Although the majority were old, the Terbang Papat group at Ash-Shiddiqin Musalla is still active and consistent from 2010 until now.

\section{History of Terbang Papat}

Terbang Papat was an art that had a sense of Islam that had existed and been preserved in the Kudus community for a long time, long before the independence of Indonesia. The art of Terbang Papat was pioneered by $\mathrm{H}$. Ashlihan, who at that time was the owner of the Djangkar cigarette company and was popularized with the Holy ulama. Terbang Papat was the art of beating a tambourine-like musical instrument consisting of 4 Terbang instruments and 1 Jidor instrument. The tradition of Kudus, Terbang Papat had existed since the Indonesian nation was still colonized, namely in 1936. By the scholars, Terbang Papat was also a medium for scholars resistance to colonialism, when the colonizers forbade people from carrying out their cultural and religious rituals, Terbang Papat was an attraction for the community. Finally, the colonialists' attempted to alienate society with their cultural and religious rituals were thwarted. At that time, the colonizers made efforts to physically and mentally colonize the community through the melean culture in which there was domino (gambling). "From here the Muslims counteracted the tradition of Papat Fly while reading prayers until midnight, slowly the tradition of judging was replaced"

After the colonial period in Kudus ended, the development of Terbang Papat was very rapid and eventually it was widespread throughout the Kudus area, up to the village group. However, in 1970-1988 Terbang Papat, its existence had decreased due to the entry of Rebana Habsyi art in Kudus. As a new art, Habsy's art had also succeeded in attracting the interest of the Kudus community, especially the younger generation, due to its more vibrant and lively playing used a more varied tambourine musical instrument. Apart from Habsyi, there were several other modern arts that had started to develop in Kudus, namely Qosidah, Dangdut, Bands, and other arts. That was what made Terbang Papat existence fluctuate in several years. And in 2012 the figures, performers of the art of Terbang Papat throughout Kudus, and the Kudus government created an organization called FKTP (Forum for Communication Terbang Papat), the organization was formed because of concern about the diminishing interest of the community, especially the younger generation (Relianto: 2015).

\section{The form of Terbang Papat Music at Ash- Shiddiqin Musalla}

The musical elements described by the researcher were in the form of parts or not as a whole in one song, because the song sung at the Terbang Papat at Ash-Shiddiqin Musalla was a long duration prayer, and as a whole is in the form of repetition of melodies and rhythmic music in terms music is called repetition, so one song could take up to 50 minutes. The researcher will present one of the poetic texts sung by the performer of the Terbang Papat art at Ash-Shiddiqin Musalla.

The Terbang Papat at Ash-Shiddiqin Musalla had two main patterns, namely clone and kongsengan. Klonengan was a pattern that was played when singing the question text in the book of Alberjanzi, and at the beginning of the song, klonengan pattern was used to adjust the vocals, and the sound of the Terbang Papat and Jidor performance, so that the sound could be one and harmonious, because usually at the beginning of the song began with a vocal, after that followed by the voices of Terbang Papat and Jidor. After that there was a kongsengan pattern, a pattern that was played when singing the answer text in the book of Alberjanzi, but when it came to the end of the song, usually the kongsengan pattern had a fast tempo, usually it called the ngejros pattern. When playing Terbang Papat, the klonengan pattern and kongsengan 
pattern were played 2 times, as if they were taking turns. For example, when the klonengan pattern was changed to the kongsengan pattern, the error pattern would be marked, to indicate when changing the performance pattern. So usually the line pattern in the Terbang Papat at Ash-Shiddiqin Musalla, namely: klonengansalahan-kongsengan-salahan-: klonengan-salahanngejros-salahan.

Based on the interview with $\mathrm{Mr}$. Kasdono, it can be understood that in the Terbang Papat at Ash-Shiddiqin Musalla performance, there were 2 main rhythmic patterns, consisting of klonengan and kongsengan patterns. (1) Klonengan was a pattern that was played when singing the question text in the book of Alberjanzi, and at the beginning of the song the klonengan pattern was used to arrange vocals, and the sound of the Terbang Papat and Jidor performance, so that it became a good and harmonious musical composition, because usually at the beginning of the song began with vocals, followed by the sound of Terbang Papat and Jidor. (2) Kongsengan, which was the pattern played when singing the answer text in the book of Alberjanzi, but when in the end of the song, usually the tempo of the kongsengan pattern became fast, the change in tempo of the kongsengan pattern was known by the performers of the Terbang Papat art at AshShiddiqin Musalla with the ngejros pattern term. In the Terbang Papat at Ash-Shiddiqin Musalla performance, the klonengan pattern and the kongsengan pattern were played 2 rounds, alternately. When the klonengan pattern changed to the kongsengan pattern or vice versa, it was marked with an error pattern, to give a sign when the transition/ performance pattern changed. So in the Terbang Papat performance at Ash-Shiddiqin Musalla had the following performance pattern sequence: klonengansalahan-kongsengan-salahan-klonengan-salahanngejros-salahan. In the Terbang Papat at AshShiddiqin Musalla which formed a single musical unit, namely the elements of time and melody which will be described by the researcher as follows:

\section{Time Element}

Music is an art whose melody is in the form of sound. Sounds produced by human voices or musical instruments played by humans basically run within a certain period of time or it could be said to be timing. This agrees with Miller (2017: 26) that music is an art that existed at the time; the medium was the actual (bodily) sound, which was not fixed but moves in a span of time. These factors were used by researchers in analyzing music on the Terbang Papat at Ash-Shiddiqin Musala that run at a certain time as follows:

\section{Tempo}

The term tempo is derived from Italian which means time. If it is used in the term music indicates sooner or later. Music can move at a very, medium, or slow pace, and in varying degrees between them (Miller 2017: 26). This is confirmed by Benward \& Saker (2008: 393) which states that tempo is the speed of rhythm in music, which can be expressed in general or in beats per minute.

The researcher gave a change in tempo in the Terbang Papat performance at AshShiddiqin Musalla in the form of a graphic which can be seen in the picture.

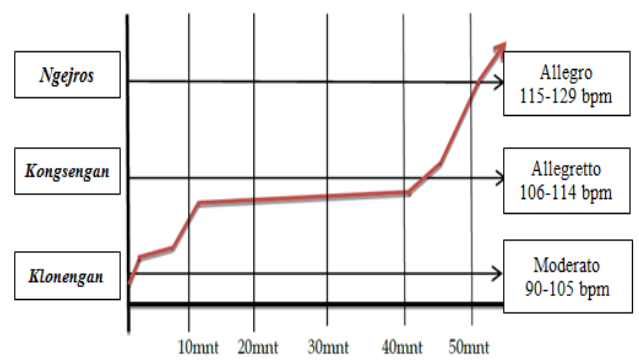

Information:

bpm : beat per minute (tempo in a minute) / steps in every minute

mnt : minute

Figure 4.The change of tempo in the Terbang Papat performance pattern

(Source: Mylza, 2020)

The tempo change in the Terbang Papat performance at Ash-Shiddiqin Musalla pattern in Figure 5., can be seen from the graph above 
that every change of the rhythmic pattern in the Terbang Papat performance at Ash-Shiddiqin Musalla, the tempo is faster, from the beginning the klonengan pattern uses a Moderato tempo (medium) with speed of 90-105 steps per minute, then the tempo began to rise to Allegretto (rather fast) with a speed of 106-114 steps per minute, and reaches its peak in the ngejros (fast) pattern with a speed of $115-129$ steps per minute

\section{Meter}

Meter is a term that is generally called a sign of sukat in a musical composition. The sign of sukat in music is the number of beats that existed on each measure and was generally written/ indicated at the beginning of the bar in a musical notation score. As stated by Miller (2017: 228) that in writing scores, the meter is indicated by a sign which shows the number of beats for a bar. So based on the results of observations of researchers in the Terbang Papat performance at Ash-Shiddiqin Musalla, then writing a musical notation in the form of a notation transcript can be seen that the meter used in the Terbang Papat performance at AshShiddigin Musalla is $4 / 4$, it means that there were four quarter notes of four beats on each measure. This $4 / 4$ sukat sign could be seen in Figure 5.2 which was written at the beginning of the bar/ in a klonengan pattern:

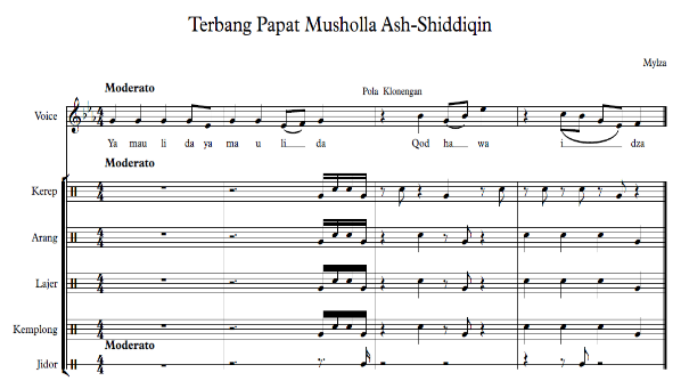

Figure 5. Sukat $4 / 4$ in song notation of Terbang Papat

(Transcript: Mylza, 2020)

\section{Rhythm}

Rhythm is a time element in music that resulted from duration and accent (Salim in Hidayatullah 2015: 29). Duration (short or length of note) is a variety of musical notes that run in a certain time. Whereas an accent is an emphasis, or emphasis on a tone to make it sound louder. The rhythm of the Terbang Papat performance at Ash-Shiddiqin Musalla had 2 types of main rhythm patterns which were played repeatedly up to two rounds in each game. The pattern consistsed of a klonengan pattern that was played when the artist sang the question text in the Alberjanzi book, and the kongsengan pattern that was played when the artist sang the answer text in the Alberjanzi book.

Notation of Jidor's rhythm:

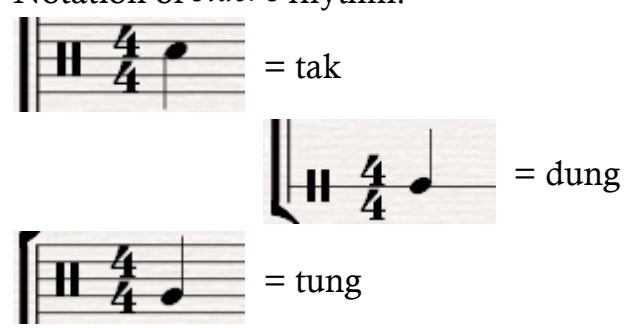

Figure 6. Rhythm notation of Terbang Papat pattern (Transcript: Mylza, 2020)

The rhythm notation in Figure 6 is a musical instrument of Terbang Papat performance at Ash-Shiddiqin Musalla which consisted of four Terbang Papat instruments, namely: Arang, Lajer, Kerep, Kemplong and one Jidor. In the Terbang instrument, it was hit in 2 different parts (the top and middle edges) which were written in rhythm notation with 5 horizontal lines and produced tak and tung sounds. On the Jidor instrument, it was hit on 1 part (middle part) which was written on rhythm notation with 1 line stretching horizontally and produced a dung sound. Although the four Terbang instruments had the same sound, tak and tung, each Terbang musical instrument had a different rhythm pattern.

Based on the three types of rhythm patterns of the Terbang Papat at Ash-Shiddiqin Musalla, it shows that there were differences in the rhythm pattern. The klonengan pattern used the note values of 1 and $1 / 2$ but when the fill-in (2nd bar) used the $1 / 8$ note, all Terbang 
instruments played simultaneously, each beat sounded tung tak-tak tung. On the 3rd bar, the Terbang Kerep instrument started on the 1 st beat $23 \frac{1}{2}$, each beat sounded tak tung tak, the 4 th bar started on the 1 st beat $21 / 221 / 231 / 2$ each beat sounded tak tak tung and the two measures were played repeatedly in a klonengan pattern. Whereas on the Terbang Arang, Lajer, and Kemplong played the same rhythm pattern in a klonengan pattern, started on the 2 nd $3 \frac{1}{2}$ beat, each beat sounded tak tung and the 4th bar started on the $1^{\text {st }}$ beat 1234 respectively which tak tak tak tung and the two bars were played repeatedly in a klonengan pattern. And on the Jidor instrument it was played on fill-in (bar 2) started on the $4^{\text {th }}$ beat $3 / 4$ which sounded dung, for the $3^{\text {rd }}$ bar the Jidor instrument was not played and the $4^{\text {th }}$ bar started on beat $21 / 2$ with a dung sound and the second the measure was played repeatedly in a klonengan pattern.

In the kongsengan rhythm pattern, the note values were $1,1 / 2$ and $1 / 8$. On the Terbang Kerep instrument, the tapping started at $1 \frac{1 / 2}{2} \quad \frac{1}{2}$ $3 \frac{1}{2} 4 \frac{1}{2}$, each of which sounded like tak tung tak, which was played in each bar repeatedly in a kongsengan pattern. On the Terbang Arang instrument, started from tapping the 1234 , each beat sounded like tak tung tung which was played on each bar repeatedly in a kongsengan pattern. On the Terbang Lajer instrument, it started beating to $1 \frac{1 / 2}{2} 344 \frac{3}{4}$, each of which sounded a timeless beat that was played repeatedly in a kongsengan pattern. In the Terbang Kemplong instrument, it started on the beat $122 \frac{1}{2} 3 \frac{1}{2} 4$, each beat sounded tak tung tung which was played on each bar repeatedly in a kongsengan pattern. Whereas in the Jidor instrument pattern, the rhythm pattern was different from the Terbang instrument whose rhythmic pattern was repeated every time. On bar 1 started on beat 1234 , each beat sounded dung dung dung dung. The $2^{\text {nd }}$ and $4^{\text {th }}$ bars had the same rhythm pattern started on the $2^{\text {nd }}$ beat $31 / 23$, each beat sounded dung dung dung. On the $3^{\text {rd }}$ bar started on the $2^{\text {nd }}$ beat 4 , each beat sounded dung dung. And the four bar patterns were played repeatedly in a kongsengan pattern.
In the rhythm pattern, salahan used the note values of $1,1 / 2$ and $1 / 8$. In the Terbang Kerep instrument, each of the 4 bars had a different rhythm pattern. On the $1^{\text {st }}$ bar started on the beat to $1 \frac{1}{2} 2 \quad \frac{1}{2} \quad 3 \quad \frac{1}{2} \quad 4 \quad \frac{1}{2}$, each beat sounded tak tak tak tung tak. On the second bar, it started on the second beat, $1 \frac{1 / 2}{2} 2 \frac{1}{2} 3 \frac{1}{1 / 2} 44$ $1 / 2$, each beat sounding not without waiting. On the $3^{\text {rd }}$ bar started on beat $13 / 421 / 23 \frac{3}{4} 4 \frac{1}{2}$, each beat sounded tung tak tung tak. And on the $4^{\text {th }}$ bar started on the beat $1 \frac{1 / 2}{2} 1 / 23 \frac{1}{2}$, each beat sounded tung tung tung. And the pattern of the four bars was played repeatedly in a fault pattern. In the Terbang Arang instrument, each measure had the same rhythm pattern and was repeated in an error pattern starting on the beat 123 4, each beat sounded tak tung tak tung. In the Terbang Lajer instrument on the $1^{\text {st }}$ and $2^{\text {nd }}$ bar had the same rhythm pattern starting on the beat $1 \frac{1}{1 / 2} 2344 \frac{3}{3}$, each beat sounded tak tak tung tak, on the $3^{\text {rd }}$ bar it started at the beat $1 \frac{1 / 2}{2}$ $223 / 4 \quad 3 \quad 1 / 2443 / 4$, each beat sounded tung tung tak tung tung tak and on the $4^{\text {th }}$ bar started on the beat $1 \frac{112}{2} 2 \quad 3 / 4 \quad 3 \quad 1 / 24$, each beat sounded tung tung tak tung tung, the pattern of four bars were played repeatedly in salahan pattern. On the Terbang Kemplong instrument, each measure had the same rhythm pattern and was repeated in the salahan pattern started at the beat of 122 $1 / 23 \frac{1}{2} 4$, each beat sounded tak tak tak tung tung. And on the Jidor instrument, bar 1, bar 3, bar 4 started on beat 24 , each beat sounded dung dung, while bar 2 started on beat $2 \frac{1}{2} 34$, each of which sounded dung dung dung. And the four bar pattern was played repeatedly in the salahan pattern.

\section{Melody}

Melody is a sequence of notes related to the high and low and the length of the notes (Miller 2017: 26-33). Meanwhile, according to Reed Sidnell (1978: 104) that a melody can be considered as a regular and horizontal sequence of tones that are heard as a dominating line. So between two statements and associated with the results of document studies in the form of transcript of notation, it could be seen that the melody in the art of Terbang Papat at Ash- 
Shiddiqin Musalla could be seen from the vocal sound sung/ sung by the performer of the Terbang Papat art at Ash-Shiddiqin Musalla which of course had a low and height, the length and sort of the tones were regular and horizontal. The melody of the Terbang Papat song at Ash-Shiddiqin Musalla consisted of the melody of the question / sentence text (phrase) and the answer text/ sentence (phrase) which was sung together by the performers of the Terbang Papat art, the vocal text came from the book of Alberjanzi. In reading the book, the vowel of the Terbang Papat at Ash-Shiddiqin Musalla did not use recitation. Tajweed is the science of translating punctuation in reading Arabic script, and the provisions (rules) of reading Arabic script.

The following is an example of the first verse (question text) of a song entitled "Yamaulida" or the popular title "Yale-yale Yama" which corresponds to the writing in the book of Alberjanzi:

Yaa maulida qodhawaa ngidz wwa iqbaa laa Biwas lihii yablukhul mustaa qua maala

The following is an example when the text was applied to the vocal presentation of the Terbang Papat at Ash-Shiddiqin Musalla vocal: Yamaulida yamaulida qodhawaa idza (senggakan: Allah yale-yale yama maul- ya-

maula) qodhawaa idza waaiq baalaa

Biwas lihiii biwas lihii yabnu hull mustaa, yabnuhull musta yabnuhulll musta quamala

The senggakan text contained in bar $5-8$ (part of the text in brackets) was taken from the answer text used by the Terbang Papat at AshShiddigin Musalla. The following is the text of the answer to the song "Yamaulida" (Yale-yale Yama) which is in accordance with Arabic script:

Ya say khuna allah ya khoyruman

(Allah yale-yale-yale yama maula- ya maula) ya ha biy biy allah ya khoiruman ya sayyidiy ladzi sulton syarif (ya allah)

The following is an example when the text was applied to the vocal presentation of the Terbang Papat:

Ya say khuna Ya say khuna allah ya khoyruman (Allah yale-yale-yale yama maula-ya maula) ya ha biy biy, ya ha biy biy allah ya khoyruman ya sayyidiy, ya sayyidiy yulladzi sulton, sulton syarif sulton syarif (ya allah)

The answer text is a special text made by the elders in Kedungdowo village which was used specifically by the Terbang Papat Group at Ash-Shiddiqin Musalla. The text was always placed after two lines in the book of Alberjanzi. So it could be concluded that the text in the book of Alberjanzi on the song entitled "Yamulida" ("Yale-yale Yama") was a question text.

The main point is the vocal presentation of the Terbang Papat at Ash-Shiddiqin Musalla, namely two lines from the book of Alberjanzi was interpreted as one verse (ask), then continued by placing the answer vowel text made by the elder of Kedungdowo village which was interpreted as one verse (answer). This pattern was repeated until the text of each verse (question) in the song entitled "Yamaulida" ("Yale-yale Yama") contained in the book of Alberjanzi was finished.

\section{Characteristics of the Accompanying Instrument of Terbang Papat at Ash-Shiddiqin Musalla}

The sound/ music in the Terbang Papat performance at Ash-Shiddiqin Musalla could be classified into 2 types, namely; internal sounds (vocals from the performers of the Terbang Papat art) which played a role in singing the sholawat verses contained in the book of Alberjanzi and external sounds (the Terbang Papat instrument) which functioned as a performance accompaniment, an atmosphere builder, as well as an illustration (Jazuli in Arisyanto, Cahyono, and Hartono 2017: 79; Rustiyanti 2014: 153). The accompaniment instruments used in the Terbang Papat at Ash-Shiddiqin Musalla consisted of 4 Terbang instruments and 1 Jidor.

\section{Terbang}

In terms of the organology aspect, the Terbang instrument was a percussion instrument made of 3 materials, namely; (1) jackfruit wood which was used as the 
instrument frame and sound-producing resonator chamber on the membrane which was hit by hand, (2) goat skin used as a membrane which was used as the sound source of the Terbang instrument spread out on the Terbang instrument frame, (3) the plate copper or what was often referred to kecrek which was used as an accessory to the sound of Terbang made the sound of Terbang seem busier. There were four Terbang instruments used in the Terbang Papat at Ash-Shiddiqin Musalla. The following is a picture of the four Terbang instruments.

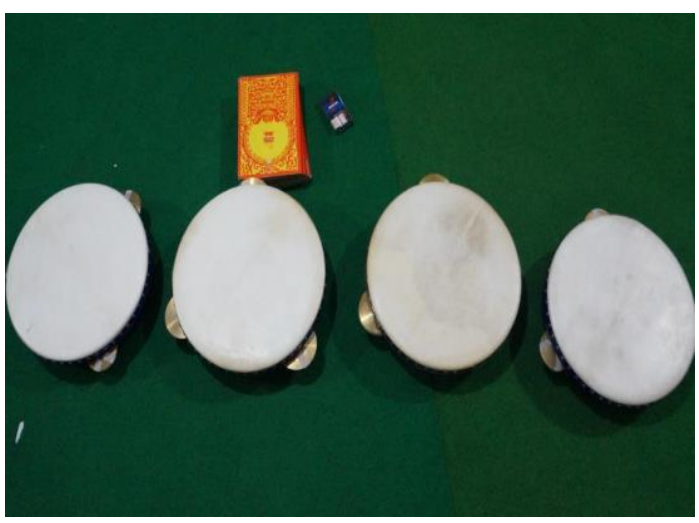

Figure 7. Terbang Instrument

(Source: Mylza, 2020)

The sound of the Terbang instrument being hit by the performer of the Terbang Papat art at Ash-Shiddiqin Musallla produced 2 different types of sound, namely; 1) The sound of Tak resulted from a hand strike on the membrane edge of the Terbang instrument; (2) the sound of Tung resulted from a hit in the middle of the membrane of the Terbang instrument. The Terbang Instrument was played in a sitting cross-legged position, the body position was facing the Terbang instrument, the right hand was used to hit the membrane of the Terbang instrument and the left hand was used to carry the Terbang instrument in a standing/ vertical position.

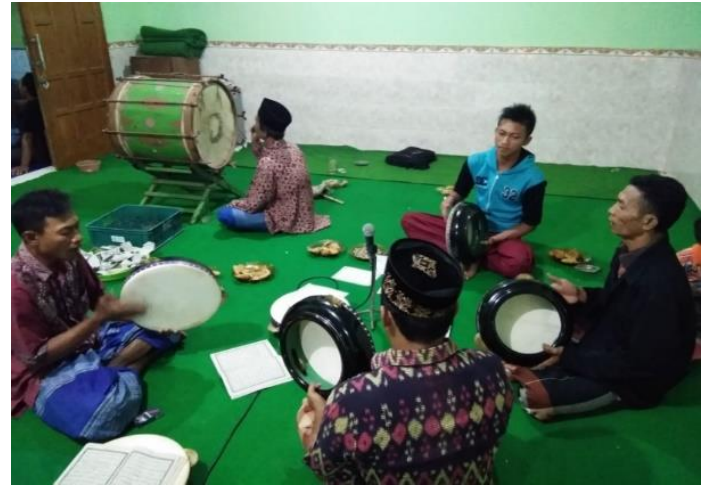

Figure 8. The position of the Terbang Papat art performers in playing the Terbang instrument (Source: Mylza, 2020)

When playing Terbang Papat, the performers of the Terbang Papat art played Terbang in a circular position by using 1 microphone placed in the middle, so that the volume produced from the four Terbang instruments could be balanced, but for the Jidor instrument, it didn't use a microphone because the volume produced from the Jidor instrument was sufficient to align the volume of the Terbang instrument with the volume of the Jidor instrument.

\section{Jidor}

The jidor used by the Terbang Papat Group at Ash-Ashiddiqin Musalla was a Jidor which had two faces and each face had the same diameter. The following is an example of a picture of Jidor used by the Terbang Papat Group at Ash-Ashiddiqin Musalla.

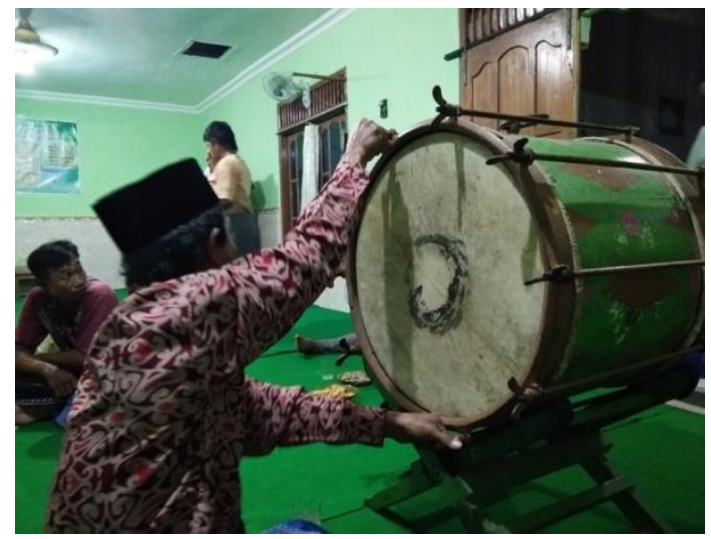

Figure 9. The Jidor instrument used in the Terbang Papat art (Source: Mylza, 2020) 
The Jidor instrument used by the Terbang Papat group at Ash-Ashiddiqin Musalla had a part to adjust (tune) the level of firmness on the membrane. In addition, the Jidor instrument had a cross-shaped support made of wood. The sound produced by Jidor was Dung played by using a stick that was hit into the middle of Jidor's membrane.

\section{Sustainability Efforts}

As one of the Terbang Papat group in Kudus, the Terbang Papat group at Ash-Shiddiqin Musalla was a Terbang Papat group that still adhered to the Terbang instrument and classical vocals (old pattern). In addition, the performers in this group were still dominated by community aged forty and over and some who were in 20s. That was what makes the Terbang Papat at Ash-Shiddiqin Musalla exists until now. The classic form (old pattern) that was maintained by the Terbang Papat group at AshShiddiqin Musalla also made the group known by the Terbang Papat art performers and the Terbang Papat lovers community in Kudus, because even though the development of the Terbang/ Tambourine music was getting faster but the Terbang Papat group at Ash-Shiddiqin Musalla still maintained the originality of the Terbang Papat music form at Ash-Shiddiqin Musalla. From the beginning of the Terbang Papat at Ash-Shiddiqin Musalla until now, the form of the Terbang and Jidor instruments had remained the same, as well as the books used still was the Alberjanzi book.

\section{CONCLUSION}

The music form of Terbang Papat at AshShiddiqin Musalla could be seen from several musical elements that had not changed due to its preservation. The community considered that the Terbang Papat Group was qualified to be used as a barometer, especially the 'classic' type of Terbang Papat (still a pure tradition). From this classic form, the Terbang Papat at AshShiddiqin Musalla was often invited to fill events in the Kedungdowo Community and its surroundings, because the role of the community made the Terbang Papat at AshShiddiqin Musalla sustainable.

\section{REFERENCES}

Abdullah, M. 2014. Pribumisasi Islam dalam Konteks Budaya Jawa dan Integrasi Bangsa. Indo-Islamika, 4 (September 2014), 67-90.

Banoe, Pono.2003. Kamus Musik. Yogyakarta.Kanisius

Benward, Bruce \& Saker, Marilyn. 2008. Music In Theory And Practice. (Eighth Edition- Volume 1). New York :McGraw-Hill.

Endarmoko. 2006. Tesaurus Bahasa Indonesia. Cet. I; Jakarta: PT Gramedia

Fitria, Yunike Juniarti. 2010."Analisis Bentuk Dan Struktur Lagu Playful Duet Karya W.A,Mozart". Jurnal Tradisi: Jurnal Seni Budaya, 1(1):69-80.

Hastanto, Sri. 1991. Kongres Kebudayaan 1991: Warisan Budaya: Penyaringan dan Pemeliharaan. Yogyakarta: Departemen Pendidikan dan Kebudayaan Direktorat Jendral Kebudayaan.

Junaidi. 2015. Estetika Terbang Hadroh Nuurussa'adah Desa Kalisapu Kecamatan Slawi Kabupaten Tegal. Semarang. Jurnal Chatarsis. Program Pasca Sarjana UNNES.: 33.

Kaelan.2012. Metode Penelitian Kualitatif Interdisipliner. Yogyakarta: Paradigma.

Martinus, Surawan.2001. Kamus Kata Serapan. Jakarta: Gramedia Pustaka.

Miller, Hugh M. 2017. Apresiasi Musik dalam Sunarto (Ed). Yogyakarta: Tafa Media.

Prier, Karl-Edmund.1996. Sejarah Musik Jilid II. Yogyakarta : Pusat Musik Liturgi.

Relianto Idih Tri. 2015. Estetika Kesenian Terbang Papat dalam Tradisi Karnaval Ampyang Maulid Nabi Muhammad SAW di Desa Loram Kulon Kecamatan Jati Kabupaten Kudus. Chatarsis: Journal of Arts Education,4 (1). Semarang: Pendidikan Seni Pascasarjana UNNES. 
Rohidi Tjetjep Rohendi .2000. Kesenian

Dalam Kebudayaan. Bandung STSI

Press

2011. Metodologi Penelitian Seni: Semarang: Cipta Prima Nusantara
Sinaga, S. S. 2002. Kesenian Rebana di Pantura Jawa Tengah: Sebuah Kajian Musikologis. Semarang.

Sukari. 2012. "Upaya pelestarian kesenian daerah; musik dan lagu". Jurnal Jantra . 7 (2) : 216 - 222. 